\title{
Sorption Preconcentration and Determination of Nickel in Wastes of Heat Power Industry by Diffuse Reflection Spectroscopy
}

\author{
O. P. Kalyakina, O. N. Kononova, 'S. V. Kachin, and A. G. Kholmogorov ${ }^{\dagger}$ \\ Krasnovarsk State Lniversity, Dept. of Chemistry, 660041, Krasnovarsk, Pr. Siobodmy, 79, Russia \\ Institute of Chemistry and Chemical Technologv, Siberian Dept of the Academy of Science, \\ 660049, Krasnovarsk, Karl-Marx-Pr., 49, Russia \\ Received Hav 20,2002
}

\begin{abstract}
The present work is focused on the preconcentration of nickel and its deternination by means of diffuse reflection spectroscopy. The preconcentration of nickel was carried out by sorption on macroporous aminocarboxylic amphoteric resin ANKB-35. Based on this collector. a method to deternine nickel in wastes of heat power industry was worked out using solid-plase spectroscopy. The colored surface compound to be deternined was obtained by a preceding nickel sorption on the resin and by subsequent treatment of the concentrate obtained with definite amounts of 1-(2-pyridilazo)-2-naphtol (PAN). The Ni calibration curve is linear in the concentration range of $0.5-20.0 \mathrm{mg} / \mathrm{L}$ (sample volume is $200.0 \mathrm{~mL}$ ) and the detection linut is 0.05 $\mathrm{mg} / \mathrm{L}$. The presence of $\mathrm{Cu}^{2-}, \mathrm{Fe}^{3+} . \mathrm{Co}^{2+}$ ions as well as macrocomponents of natural water $\left(\mathrm{Na}^{-}, \mathrm{K}^{+}, \mathrm{Ca}^{2-}, \mathrm{Mg}^{2+}\right)$ do not hinder the solid-phase spectroscopy detenmination of nickel. The nickel deternination by diffuse reflection spectroscopy was carried out in model solutions as well as in solutions obtained after the dissolution of wastes of heat power industry.
\end{abstract}

Key Words : Nickel. Sorption preconcentration. Wastes of heat power industry. Diffuse reflection spectroscopy

\section{Introduction}

An irrational and ecologically dangerous handling of wastes is an urgent environmental problem. More than 25 billion tons of solid wastes are furnished annually in the world including about 7 billion tons in Russia. ${ }^{1}$ During the burning of coal. complex chemical and phase conversions occur in its mineral components. ${ }^{2}$ As a result substances with new properties are formed-ash and slag. Many microelements (nickel cobalt. copper. iron etc.) contained in natural coals are concentrated in ashes and slags. and so their content in these wastes increases several times over. That is why waste piles are one of the most active sources of environmental pollution. Their dispersion leads to the fouling of the atmosphere and of natural ground water. The latter is a result of hy'draulic disposal of ash and slag wastes. ${ }^{3}$

It should be noted that nickel produces a general toxic effect on the human organism. causing nasopharynx and lung diseases. malignant tumors and dermatological diseases as well. ${ }^{4}$ Nickel-containing sewage are harmful after ingress into water. This fact explains the importance of the monitoring of nickel concentrations in natural water and sewage. Therefore. it is necessary to analyze nickel concentrations in natural water and sewage on a level of parts of the maximum permissible concentration. which is for Russia $0.1 \mathrm{mg} / \mathrm{L}$. An analytical sorption technique can be applied here . $^{6-8}$

The solid-phase spectroscopy method combines the sorption preconcentration of metal ions and their determination on a surface of different sorbents. This method has already been shown to be advantageous for analysis of different

\footnotetext{
Corresponding author: e-mail: $\mathrm{cm} 2 \mathrm{akth} \cdot \mathrm{ru}$
}

metals as well as for their content control in electrolytes. sewage and natural water. ${ }^{9-13}$ Moreover, this method is cheap and applicable under field conditions. ${ }^{14}$

In a recent study we investigated the ion exchange recovery of nickel from manganese nitrate solutions obtained after the processing of manganese ores. ${ }^{15}$ It was shown that the aminocarboxylic amphoteric ion exchangers possess the selective sorption properties to nickel ions. The present paper is devoted to the nickel preconcentration on macroporous amphoteric resin ANKB-35 and to the Ni(II) determination by diffuse reflection spectroscopy

\section{Experimental Section}

The macroporous amphoteric ion exchanger ANKB-35 sy'nthesized on the basis of acrylonitrile and diviny lbenzene was investigated. The manufacturer of this ion exchanger is TOKEM-Company (Kemerovo. Russia).

After the standard preparation. the resin was converted into the $\mathrm{Na}^{+}$-form. The specific swelling volume and the static exchange capacity of ANKB-35 are $2.8 \mathrm{~cm}^{3} / \mathrm{g}$ and 3.6 $\mathrm{mmol} / \mathrm{g}$. respectively:

The nickel sorption was investigated under batch experiment conditions. The nickel chloride stock solution $(500 \mathrm{mg} /$ L) was prepared from an accurately weighed sample of pure supplier (analytical grade). This solution was standardized by $0.1 \mathrm{M}$ EDTA solution. The operating nickel solutions were prepared by diluting the stock solution.

Before sorption on the resin. samples $(0.2 \mathrm{~g}$ of $\mathrm{dry}$ substance) were swollen for $4 \mathrm{~h}$ in distilled water at the desired $\mathrm{pH}$ value (2.5-5.5). After swelling. the resins were stirred with $\mathrm{NiCl}_{2}$ solutions in a thermostat at $(20 \pm 1){ }^{\circ} \mathrm{C}$. 
The stirring time intervals were from $10 \mathrm{~min}$ to $24 \mathrm{~h}$. The mass ratio of resins to solutions was $1: 50$.

Apart from the individual $\mathrm{NiCl}_{2}$ solutions. model solutions were also investigated. These solutions contained $\mathrm{Ni}$ (II) ions as well as competing ions such as cobalt(II). copper(II). iron(III). mangenese(II), sodium. calcium. magnesium and fluoride. The desired $\mathrm{pH}$ values of the sample solutions were adjusted by diluted $\mathrm{HCl}$ or $\mathrm{NaOH}$. controlled by a pH-meter.

Wastes of the heat power industry of Krasnoyarsk (ash and slag pulps) were also used for the determination of nickel ion. These wastes were dissolved according to the procedure described in our paper. ${ }^{16}$

After sorption. the metal-loaded resins were separated from solutions. Then analy'ses of both solid and liquid phases were carried out. The concentration of nickel in solutions was determined by a photometrical method ${ }^{17.18}$ (PAN as a reagent) using a photocolorimeter (Model KFK-3. Russia) or by flame atomic absorption spectroscopy using an atomic absorption spectrophotometer (Model Saturn-2. Russia).

The diffuse reflection spectra of the sorbent investigated were registered by means of the transportable colorimeter (Model Spectroton. Russia). For this purpose the wet samples $(0.2 \mathrm{~g})$ were placed into a cell and the spectra were recorded at a wavelength of $380-720 \mathrm{~mm}$. The cell is a fluoroplastic disk (height is $10 \mathrm{~mm}$. diameter $80 \mathrm{~mm}$ ) with a cylindrical hole of $5 \mathrm{~mm}$ depth and $16 \mathrm{~mm}$ diameter).

The desired analyte compound was obtained on the resin surface according to the following procedures:

Formation of nickel chelate with PAN in the resin phase. $0.2 \mathrm{~g}$ of ANKB-35 and nickel solutions contained $0.34-3.4 \mathrm{mmol} \mathrm{Ni}{ }^{2+} / \mathrm{L}$ were placed into graduated flasks $(\mathrm{V}=25.0 \mathrm{~mL})$ and the suspensions were stirred over a period of $30 \mathrm{~min}$. Then the resins were filtered and $0.2 \mathrm{~mL}$ of $0.1 \%$ aqueous PAN solution were added drop by drop to the exchangers. After $30 \mathrm{~min}$, the diffusion reflection coefficients were measured.

Sorption of nickel on the modified ion exchanger. $0.2 \mathrm{~g}$ of ANKB-35 modified by $0.1 \%$ aqueous PAN solution (modification of sorbent is the preceding reagent sorption on this resin) and nickel solutions contained 0.34-3.4 mmol $\mathrm{Ni}^{-} / \mathrm{L}$ were placed into graduated flasks $(\mathrm{V}=25.0 \mathrm{~mL})$ and distilled water was added up to the flasks mark. After the required period of time. the resins were filtered and then the diffusion reflection coefficients were measured.

In the solid-phase spectroscopy method the change of Gurevich-Kubelka-Munk function $\Delta F(R)$ is used as an analytical signal:

$$
\Delta R(R)=\frac{(1-R)^{2}}{2 R}-\frac{\left(1-R_{0}\right)^{2}}{2 R_{0}} .
$$

where $R$ and $R_{0}$ are diffusion reflection coefficients (quantities of the dimensionl) of chelate of $\mathrm{Ni}^{2+}$ with PAN in the exchanger phase and of the ion exchanger. respectively. $19-21$

The determination of the composition of $\mathrm{Ni}$ (II) complex compound with PAN in the resin phase was carried out by the method of isomolar series according to the following procedures:

(1) $1,2,3,4,5,6,7,8$ and $9 \mathrm{~mL}$ of $\mathrm{Ni}$ (II) solution $\left(1 \times 10^{-3}\right.$ $\mathrm{mol} / \mathrm{L}$ ) and $9.8 .7 .6 .5,4.3 .2$ and $\mathrm{lmL}$ of PAN solution $\left(1 \times 10^{-3} \mathrm{~mol} / \mathrm{L}\right)$ were placed into graduated flasks $(\mathrm{V}=25.0$ $\mathrm{mL}$ ). Then distilled water was added up to the flask s mark. After that $0.2 \mathrm{~g}$ of ANKB-35 was added and the suspensions were stirred over a $1 \mathrm{~h}$ period. Then the resins were filtered and the diffusion reflection coefficients were measured at $\lambda=560 \mathrm{~nm}$.

(2) 1. 2. 3. 4. 5. 6, 7,8 and $9 \mathrm{~mL}$ of $\mathrm{Ni}$ (II) solutions $\left(1 \times 10^{-3} \mathrm{~mol} / \mathrm{L}\right)$ were placed into graduated flasks $(\mathrm{V}=25.0$ $\mathrm{mL}$ ) and distilled water was added up to the flask s mark. After that, $0.2 \mathrm{~g}$ of ANKB-35 was added and the suspensions were stirred over a $1 \mathrm{~h}$ period. Then the resins were filtered and placed into the PAN solutions with different concentrations. These solutions were obtained by the following way: $9.8,7,6,5,4,3.2$ and $1 \mathrm{~mL}$ of PAN $\left(1 \times 10^{-3} \mathrm{~mol} / \mathrm{L}\right)$ were placed into graduated flasks. Then distilled water was added up to the flask's mark. After l h. the resins were filtered again and the diffusion reflection coefficients were measured at $\lambda=560 \mathrm{~mm}$.

Using the results obtained. the isomolar diagram was plotted in the coordinates $\Delta F(R)-X$. where

$$
X=\frac{C_{\mathrm{R}}}{C_{\mathrm{M}}+C_{\mathrm{R}}}
$$

( $C_{\mathrm{M}}$ and $C_{\mathrm{R}}$ are the molar concentrations of the metal ions and reagent solutions, respectively).

The composition $(n)$ of the complex compound was determined according to the following formula:

$$
n=\frac{1-X_{\max }}{X_{\max }} .
$$

where $X_{\max }$ is the value of $X$. which corresponds to maximum on the isomolar diagram.

All results were statistically processed by standard methods ${ }^{2 t}$. the average for 3-4 parallel tests was measured, then the variance. standard deviation and confidence intervals were calculated using Student's $t$ at $P=0.95$. The standard deviation of the total analytical procedure was not more than $8 \%$.

\section{Results and Discussion}

In the previous work. ${ }^{14}$ the optimum $\mathrm{pH}$ values for nickel sorption on amphoteric ion exchangers were determined. The $\mathrm{pH}$ increase from 2.5 to 5.5 leads to the rise in exchange capacity in the $\mathrm{Na}^{+}$-form because the concentration of coordination-active (non-protonated) functional groups decreases with the increase in the solutions' acidity ${ }^{33.24}$ It was found that $\mathrm{pH}>3.5$ is suitable for selective $\mathrm{Ni}$ (II) recovery.

The sorption isotherm obtained under the optimum conditions is convex (i.e. the selective Ni(II) sorption) (Figure 1).

We have found that the IR-spectra of ANKB-35 vary after the Ni(II) sorption (Figure 2). The intensity of absorption bands at $1800-1600 \mathrm{~cm}^{-1}$ and at $300-250 \mathrm{~cm}^{-1}$ has the following changes: disappearance of absorption band at $1730-1720 \mathrm{~cm}^{-1}$ and the widening of the band at $1400-1370$ 


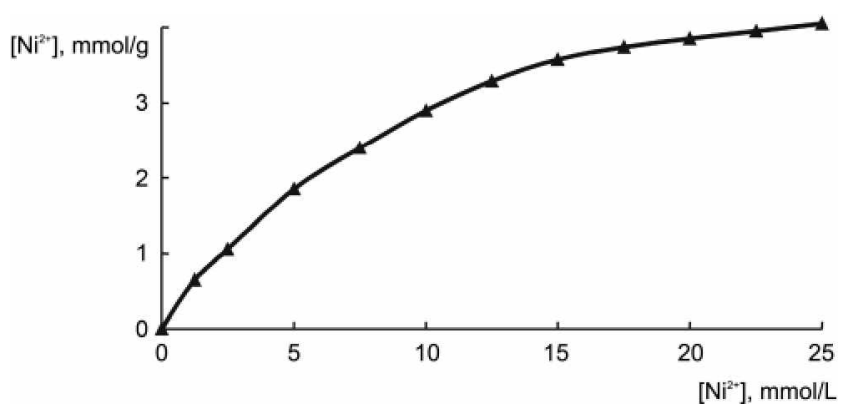

Figure 1. Isotherm of Ni(II) sorption on amphoteric ion exchanger ANKB-35

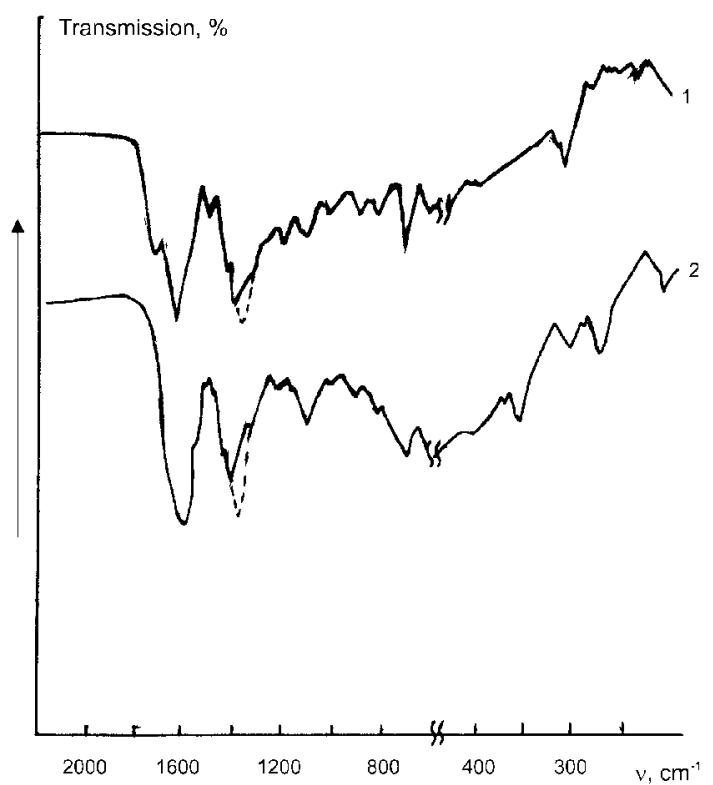

Figure 2. IR spectra fragnents of anphoteric ion exchanger ANKB-35. 1-Na ${ }^{-}, \mathrm{Cl}^{-}$-fon, $\mathrm{pH}=3.3-3.5 .2-\mathrm{Ni}^{2-}$-fonm, $\mathrm{pH}=3.5$.

$\mathrm{cm}^{-1}$. These bands are in conformity with asymmetric and symmetric vibrations of ionized carboxylic groups. The location of frequencies $v_{\mathrm{s}}$ and $v_{\mathrm{as}}$ changes after the $\mathrm{Ni}^{2+}$ sorption $\left(\Delta v=210 \mathrm{~cm}^{-1}\right)$. It can be assumed that the complex compounds of $\mathrm{Ni}^{2+}$ with the sorbents functional groups are formed in the ion exchanger phase. Moreover. the bands. which appear at 320 and $380 \mathrm{~cm}^{-1}$. can be attributed to the complex bonds of nickel with nitrogen and oxygen atoms of functional groups of the resin. 15.25 The data obtained allows one to assume that the following complexes are formed in the phase of ANKB-35:

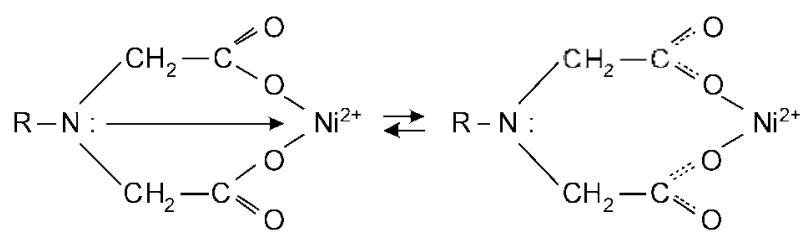

Metal reagent PAN (1-(2-py'ridy lazo)-2-naphtol) is highly selective for determination of nickel by the photometrical method. ${ }^{17}$ Therefore. this reagent was also used for sorptionspectroscopic nickel determination in wet resin phase. For

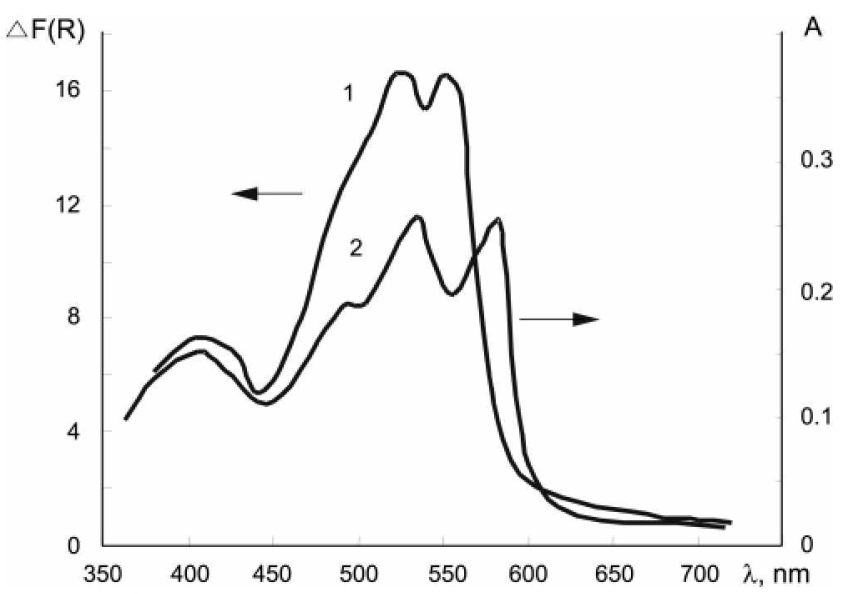

Figure 3. Diffuse reflection spectra of the nickel chelate with PAN in the phase of ANKB-35 ( 1 ) and of the nickel chelate with PAN in the solution (2). Content of $\mathrm{Ni}(\mathrm{II})$ in the resin phase is $40 \mu \mathrm{g}(1)$; $C_{V_{l}}=3.4 \mathrm{mmol} / \mathrm{L}(2)$.

this purpose. diffuse reflection spectra were recorded for the nickel chelate with PAN in the resin phase and in the solution (Figure 3. curves 1 and 2, respectively). It can be seen from this Figure that both spectra are similar to each other. but the maxima in diffuse reflection spectrum (Figure 3. spectrum 1) are shifted to a range of short wavelength in comparison with these maxima in spectrum of Ni-PANcomplex in a homogeneous medium (Figure 3, spectrum 2). Possibly, a matrix effect takes place.

It is known ${ }^{21}$ that the colored surface compound can be obtained by a preceding nickel sorption on the resin with the subsequent treatment of the concentrate obtained with a definite amount of PAN or by a preceding sorption of PAN on the resin. with the subsequent nickel sorption on the modified sorbent.

In the first case. nickel sorption on ANKB-35 proceeds in accordance with the ion-exchange mechanism

$$
2 \overline{\mathrm{RNa}}+\mathrm{Ni}^{--} \rightarrow \overline{\mathrm{R}_{-} \mathrm{Ni}}+2 \mathrm{Na}^{+} .
$$

followed by a treatment with a definite amount of PAN. In the second case. a physical adsorption of PAN is probable between the macroporous resin and reagent.

The question regarding the binding form of the Ni-PANcomplex to the ion exchanger requires additional study. It is known ${ }^{26}$ that PAN forms complexes with metals in solution by means of hydroxyl group oxygen atoms of as well as by nitrogen atoms of pyridyl and azogroups:

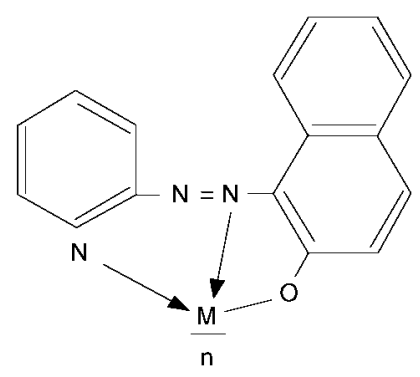




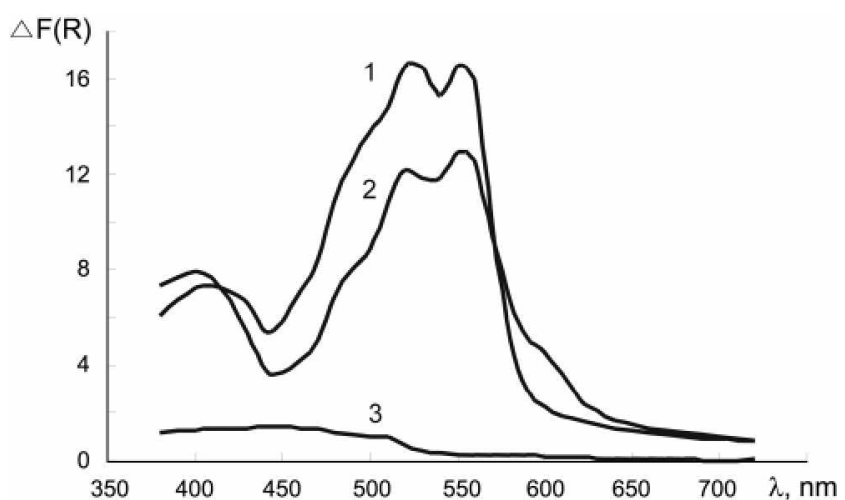

Figure 4. Diffuse reflection spectra of sorbates of the nickel chelate with PAN $(1,2)$ and of PAN (3). 1-PAN is added to the sorbent in the $\mathrm{Ni}^{2+}$-fom. 2-Sorption of Ni(ll) by the modified resin. Content of $\mathrm{Ni}(\mathrm{II})$ in the resin phase is $40 \mu \mathrm{g}$.

It is probable that ion-pair binding appears between the Ni-PAN-complex and carboxylic groups of the exchanger or an unspecific sorption interaction can take place.

The diffuse reflection spectra of sorbates of the Ni-PANcomplexes and of PAN are shown in Figure 4. It should be noted that the procedure of synthesis of the colored compound in the sorbent phase has no effect on the location of maxima in diffuse reflection spectra (Figure 4. spectra 1 and 2). but the analytical signal is more pronounced when the nickel-PAN-complex is formed in the sorbent phase (see Experimental. procedure 1).

Furthermore the dependence of analytical signal on time and on $\mathrm{pH}$ was investigated at the wavelength $560 \mathrm{~mm}$. It was found out that the equilibrium state was attained during 30 $\mathrm{min}$. The peak of analytical signal was observed at $\mathrm{pH}=4.5$ 8.0 (Figure 5).

The ratio $\mathrm{Ni}^{-}$:PAN in the sorbent phase is $1: 1$ based on method of isomolar series (Figure 6).

It is known ${ }^{17}$ that $\mathrm{Cu}^{2+}$. $\mathrm{Fe}^{3+}$ and $\mathrm{Co}^{2+}$ ions can interfere in the spectrophotometric analy'sis of nickel. These ions were masked by fluoride and thioglycol acid. The results of nickel determination in the presence of these components are

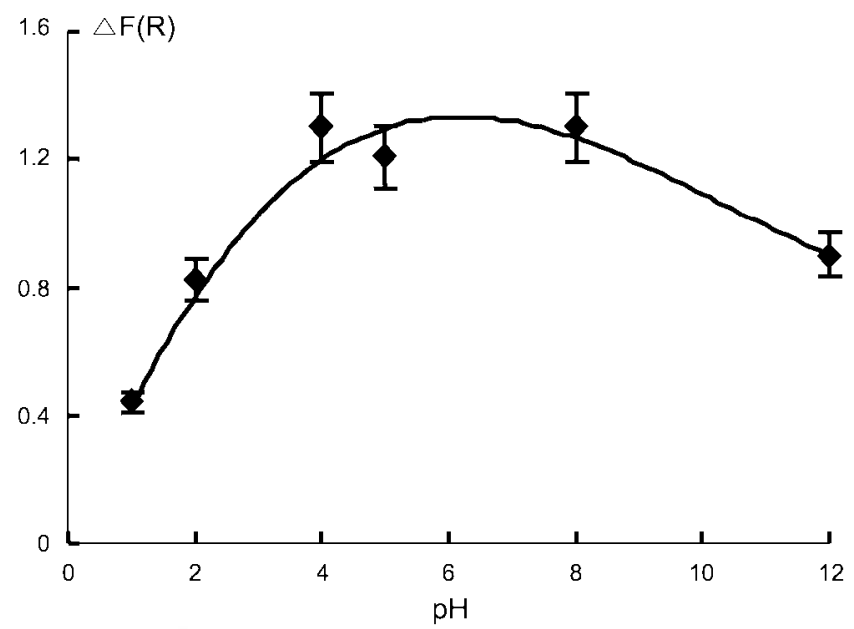

Figure 5. Eftect of $\mathrm{pH}$ on formation of analytical signal. $\lambda=560$ $\mathrm{nm}$; nickel content in the exchanger phase is $5 \mu \mathrm{g}$

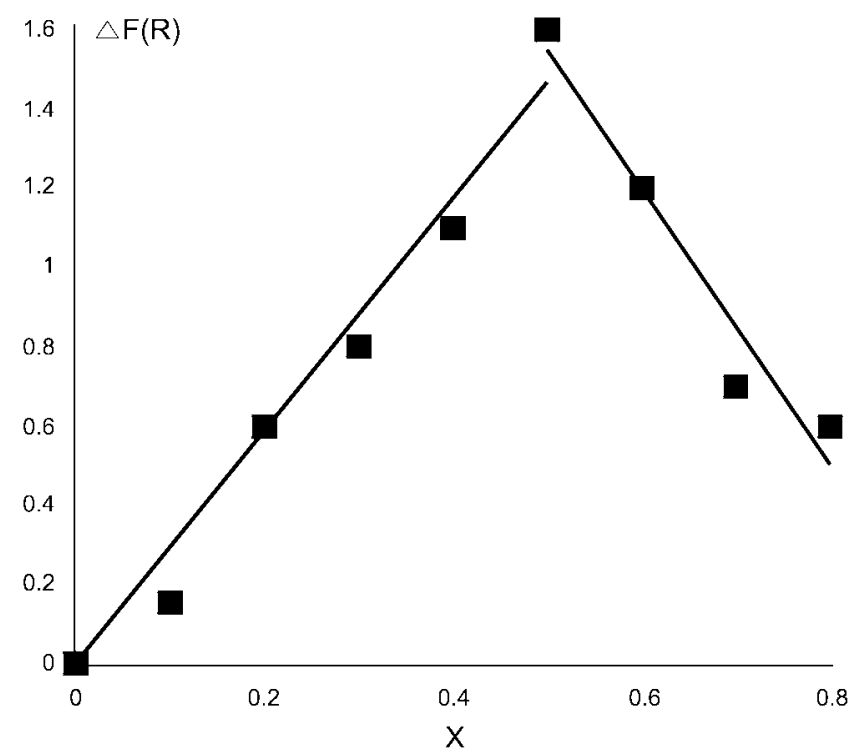

Figure 6. Isomolar diagram of $\mathrm{Ni}(\mathrm{II})$-PAN-complex in the phase of ANKB-35. $C_{\mathrm{N}_{1}}=1 \times 10^{-3} \mathrm{~mol} / \mathrm{L} ; \mathrm{C}_{\mathrm{PAV}}=1 \times 10^{-3} \mathrm{~mol} / \mathrm{L}$.

summarized in Table 1. It can be seen from Table 1 that the presence of the above-mentioned ions as well as of macrocomponents of natural water $\left(\mathrm{Na}^{+}, \mathrm{K}^{-}, \mathrm{Ca}^{2-}, \mathrm{Mg}^{2+}\right)$ do not hinder the solid-phase spectroscopy detenmination of nickel.

Based on the results obtained. a number of sorptionspectroscopic detenminations of nickel were carried out in a series of water samples. For that purpose. standard nickel solutions $(0.1-20.0 \mathrm{mg} / \mathrm{L})$ were placed into graduated flasks $(V=250.0 \mathrm{~mL})$. Then $0.2 \mathrm{~g}$ of resin, preswollen at a definite $\mathrm{pH}$ value and $10 \mathrm{~mL}$ of $4 \% \mathrm{NaF}$ solutions were added and the suspensions were stirred over a period of $30 \mathrm{~min}$. After that the resins were filtered and $0.2 \mathrm{~mL}$ of $0.1 \%$ PAN solution were added drop by drop to the exchangers. Then $10 \mathrm{~mL}$ of $0.1 \mathrm{M}$ thioglycol acid solution was added to the colored resins and the suspensions were stirred over a period of $10 \mathrm{~min}$. After that the ion exchangers were filtered again and the diffusion reflection coefficients were measured at $560 \mathrm{~nm}$ and the calibration curve of $\Delta F(R)$ was plotted as a function of the $\mathrm{Ni}^{-}$concentration.

Table 1. Eftect of foreign ions on the detemination of nickel ion by solid-phase spectroscopy

\begin{tabular}{cccc}
\hline $\begin{array}{c}\text { Foreign } \\
\text { ion }\end{array}$ & $\begin{array}{c}\text { Ratio of toreign } \\
\text { ion to } \mathrm{Ni}(\mathrm{II})\end{array}$ & $\begin{array}{c}\text { Found } \mathrm{Ni} \\
\mu \mathrm{g} / \mathrm{mL}\end{array}$ & $\begin{array}{c}\text { Relative error, } \\
\%\end{array}$ \\
\hline $\mathrm{Co}(\mathrm{II})$ & $1: 1$ & 0.98 & -2 \\
$\mathrm{Cu}(\mathrm{II})$ & $10: 1$ & 1.04 & +4 \\
& $100: 1$ & 1.38 & +38 \\
$\mathrm{Ca}(\mathrm{II})$ & $10: 1$ & 1.09 & +9 \\
$\mathrm{Fe}(\mathrm{III})$ & $10: 1$ & 1.08 & +9 \\
& $100: 1$ & 1.35 & +35 \\
$\mathrm{Mn}(\mathrm{II})$ & $10: 1$ & 0.92 & -8 \\
$\mathrm{Mg}(\mathrm{II})$ & $10: 1$ & 0.98 & -2 \\
$\mathrm{NaCl}$ & $100: 1$ & 1.02 & +2 \\
& $1000: 1$ & 094 & -6 \\
$\mathrm{~F}^{-}$ & $1000: 1$ & 0.96 & -4 \\
\hline
\end{tabular}

${ }^{a} \mathrm{C}_{\mathrm{Xi}}=1 \mathrm{mg} \mathrm{mL}$ 
Table 2. Sorption-spectroscopic nickel detennination in model solutions

\begin{tabular}{ccccccc}
\hline \multirow{2}{*}{$\begin{array}{c}\text { Analysis } \\
\text { object }\end{array}$} & \multicolumn{2}{c}{ Nickel content, $\mu \mathrm{g} / \mathrm{nnL}$} & & $\mathrm{S}_{\mathrm{i}}$ & $\pm \frac{t_{\mathrm{p}} \cdot S}{\sqrt{n}}$ & $\varepsilon, \%$ \\
\cline { 2 - 3 } & Added & found & & & \\
\hline MS I & 1.0 & 1.19 & & 0.05 & 0.09 & +19 \\
MS 2 & 5.0 & 5.18 & & 0.06 & 0.44 & +4 \\
MS 3 & 10.0 & 10.22 & 0.03 & 0.40 & +22 \\
\hline
\end{tabular}

"MS-model solution. $n=4 ; P=0.95$.

Table 3. Sorption-spectroscopic nickel detemmination in wastes of heat power industry"

\begin{tabular}{ccc}
\hline \multirow{2}{*}{ Material } & \multicolumn{2}{c}{ Ni, found $w \pm \delta, \mathrm{mg} / \mathrm{kg}$} \\
\cline { 2 - 3 } & $\begin{array}{c}\text { by sontion- } \\
\text { spectroscopic method }\end{array}$ & $\begin{array}{c}\text { by flame AAS } \\
\text { method }\end{array}$ \\
\hline Slag pulp 1 & $85.8 \pm 3.4$ & $85.1 \pm 2.1$ \\
Slag pulp 2 & $109.7 \pm 6.3$ & $97.8 \pm 4.2$ \\
Slag & $74.8 \pm 5.2$ & $72.9 \pm 3.3$ \\
Ash 1 & $78.0 \pm 5.4$ & $71.4 \pm 4.9$ \\
Ash 2 & $60.7 \pm 5.1$ & $68.6 \pm 4.3$ \\
\hline
\end{tabular}

"The slag and slag pulps were selected from difterent boilers of heat power station and the ash samples were taken from electric tilters. $n=3$ : $P=0.95$.

This calibration curve is linear at the $\mathrm{Ni}^{2+}$ concentration range of $0.5-20.0 \mathrm{mg} / \mathrm{L}$ and by sample volume of $200.0 \mathrm{~mL}$. The detection limit determined by $3 \sigma$ method is $0.05 \mathrm{mg} / \mathrm{L}$. The calibration curve follows the equation

$$
\Delta F(R)=0.1664 C_{\mathrm{Ni}}+0.0852 .
$$

Moreover. the sample volumes of $1000.0 \mathrm{~mL}$ were used for determinations of lower nickel concentrations in water.

The detection limit is $0.02 \mathrm{mg} / \mathrm{L}$ in this case and the calibration curve follows the equation

$$
\Delta F(R)=0.3526 C_{\mathrm{Ni}}+0.0995 \text {. }
$$

Based on the calibration curves obtained, a number of nickel ion determinations were carried out by sorption spectroscopy. The results are shown in Table 2.

Moreover, the nickel determination was carried out by solid-phase spectroscopy method in solutions obtained after the dissolution of wastes of heat power industry. We also compared the accuracy of the proposed method and the flame atomic absorption method. The results of comparison are given in Table 3

The results obtained allow us to reconmend the analytical systems, on the basis of macroporous amphoteric ion exchanger ANKB-35. for the ion-exchange nickel recovery from the solid wastes and for its determination directly in the sorbent phase.

Acknowledgement. Financial support for the investigations was provided by The Ministry of Education of the Russian Federation under the scientific-techuical program "Scientific Investigations of Higher Education Institutions in
Priority Directions of Science and Technology" in 2001-2002 (Project No 02.01.167)

\section{References}

1. Reymers, N. F. Ohrana Prinoty i Oknushaushohey Shed: Prosweshchenie: Moscow. Russia. 1990: p 230. Aatwe Concervation and Eniommental Control in Russian1)

2. Gonnara Encyclopedina: Kozlorskiy. E. A.. Ed: Sovetskaya Enzyklopediya: Moscow, Russia, 1985; Vol. 2. p 575. Mimmg Enzykiopaedia, in Russian)

3. Zhabo. V. V. Otrana Oknushaushchey Sredh na TES i AES; Energoatomisdat: Moscow: Russia. 1992: p 240. (Enironmental Control in Heat Power Stations and Nuclear Power Stations, in Russian1)

4. Chinticheskana Enzwhlopediva, Knunyanz. I. L.. Ed; Bolshava Rossiyskaya Enzyklopediya: Moscow, Russia. 1998; p 471. (Chemical Encyclopaedia, in Russian)

5. Fomin. R. S. Ioda. Kontrol Chimicheskoy Bakteriahoy i Radiacionnoy Besopasnosty po Heshdunarodnum Standartam: Nauka: Moscow: Russia. 1995: p 135. Water: Control of Chenical. Bacterial and Radiational Safen by Intemational Standard. in Russian)

6. Wilms. H. Sudiest. Hirt $1990,46,9$.

7. Grebenuk. V. D:- Sobolevshaya. T. T.: Makhno. A. G. Chintivi Technologiva Vody 1989.11.407

8. Me Millen. T. NLGI Spokesman 1991. 54. 24.

9. Yoshimura. K.: Waki. H.: Ohashi. S. Talanta 1976. 23.449.

10. Brykina. G. D.: Krysina, L. S.; Ivanov. V. M. J. Anal. Chent 1988. +3. 1547 .

11. Terlezkava A. V: Bogoslovskava. T. A. Chiniva i Techologiva Iod 1994. 16.338

12. Brykina. G. D.: Marchenko. D. Y.. Shpigun. O. A. J. Anal. Chem. 1995. 50.440

13. Yoshimura, K.: Toshimitsu. Y: Ohashi, S. Talama 1980, 29.693.

14. Runov, V. K.: Kachin, S. V. Zavodkfana Laboratoriya 1993. $59,1$.

15. Kononova, O. N.; Kholmogorov. A. G.; Kachin, S. V: Mytyki, O V: Kononov. Y. S.: Kalyakina. O. P.: Pashkor. G. L. Hydrometallurgu 2000. 54. 107.

16. Kalyakina. O. P.: Kononova. O. N.: Kachin. S. V.: Kholmogorov. A. G. Acta Hyochin. Huctrobiol, 2000, 28, 272.

17. Umland, F.: Janssen. A; Thierig. D.: Wünsch, G. Theorie and praktische Anwending von Konplexbildnern: Mir: Moscon: Russia. 1975: p 347.

18. Peshliova. V. M.: Savostina. V. M. Analvicheskava Chimina Nickelya: Nauka: Moscow. Russia. 1966: p 5. Analutical Chemistry of Nickel, in Russian)

19. Kubelka, P.: Munk, F. Z. Techn. Phss. 1931. 12, 593 (cited from [21]).

20. Kubelka. P. J. Opt. Soc. Amer 1948. 38.448 (cited from [21]).

21. Runov. V. L.: Tropina. V. V. J. Anal Chem 1996. 51.64

22. Pollard. I. H. A Handhook of Numerical and Statistical Techiques; Cambridge University Press: Cambridge. U.K, 1977: p 342 .

23. Kokotov, Y. A.; Pasechnik, V. A. Ronnonesie i Kinetika Iomogo Obnena: Chimiya: Lenitgrad. Russia. 1970: p 312. (Equilibria and Kinetics of Ion Exchange. in Russian).

24. Saldadze. K. M.: Kopylova-Valova. V. D. Kompleksoobrasunshche Ionity; Chimiva: Moscow: 1980; p 516. (Complex-forming Ion Exchangers. in Russian).

25. Nakamoto. K. Infraknasme Spectry Neorganicheskikh i Koordinaziomukh Soedineniv: Mir: Moscow: Russia. 1966: p 373. (IRspectra of Inorganic and Coordinating Compounds. in Russian1).

26. Burger. K. Organic Reagents in Matal Analusis. Mir: Moscow. 1975: p 148 